\title{
DRIVERS OF NATURAL RESOURCES CONSERVATION AND PARTICIPATION IN FOREST DEVELOPMENT PROGRAMMES- A SOCIO ECONOMIC ANALYSIS OF FOREST DWELLERS' ROLE IN SITTILINGI VALLEY FORESTS OF TAMIL NADU
}

\author{
S. Gurunathan and S. Govindaraj \\ Department of Agricultural Economics, Tamil Nadu Agricultural University, Coimbatore (India) \\ Email:gurunath007@email.com, Tel: +91-9894273049
}

\begin{abstract}

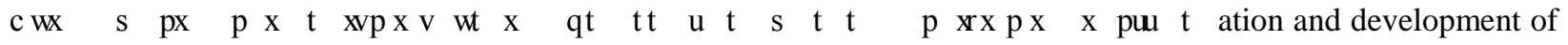
forest areas in Sittilingi valley of Dharmapuri district in Tamil Nadu and a set of socio-economic variables. A sample of 50 forest dwellers each in Sittilingi and Naikuthi village of the valley was selected to get a sample size of 100 by proportional random sampling. The result of the content validity of questionnaire (Cronbach's alpha) showed that the selected variable had high reliability. Traditional Diffusion Model of Rogerts was employed to analyse the

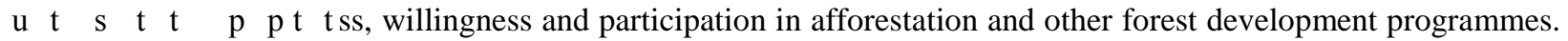
The findings revealed that age, participation in capacity building programmes, forest dependency, social participation, social solidarity, economic and social motivations are positively and significantly correlated with forest dwellers' participation in afforestation and development of forest areas. About 77 per cent of the forest dwellers expected good quality of water for conserving their natural resources. Financial and technical assistances are preferred equally by the residents of the valley as subsidy measure to adopt conservation measures. Sixty per cent of the forest dwellers were against allocating any money from their own for resource conservation. At the same time valley residents were positive towards natural resources conservation within the valley. Forest dwellers are ready to plant trees around their farm lands and homes but they felt otherwise when the case of planting in common lands and degraded land arise since they felt planting in such areas as the duty of the government. Thus the prioritization of the forest dwellers was personally inclined. Variables like, attitude, knowledge, concern for biodiversity and concern for soil fertility were significantly influencing the forest dwellers to allocate economic resources in natural resources conservation programmes in the valley. The result of multiple regression showed that variables of level of participation in capacity building programmes, size of household, age, economic motivation, social solidarity and level of literacy could explain 51.4 per cent of the variation in the level of forest dwellers' participation in afforestation and other development activities of forest areas.
\end{abstract}

Key words: Forest, forest dwellers, adoption, participation, soil erosion, conservation, impact, diffusion model

\section{INTRODUCTION}

Natural resources development at the community level increases the probability that multiple stakeholder interests will be represented in the planning and programme implementation stages. This approach to decision making is commonly termed participatory management. Focus on specific conservation issues within subsections of a forest area may exclude significant segments of forest residents. Unless the interests of all forest residents are represented in the decision-making process, conservation planning and programme implementation efforts may not achieve anticipated outcomes.

The environmental, social and economic problems created by soil erosion of agricultural land have been observed for decades in India. While farming and production technologies exist to prevent soil erosion and subsequent contamination of water resources, researches have reported that many land owneroperators refuse to adopt and use conservation production systems. This is true despite the fact that farmers value the environment, perceive themselves to be the stewards of the land, and often believe that farming contributes to environmental degradation and that pollution needs to be addressed as an environmental issue.

Proceedings of the 15 ${ }^{\text {th }}$ International Forestry and Environment Symposium, 26-27 November 2010.

Published by Department of Forestry and Environmental Science, University of Sri Jayewardenepura, Sri Lanka. 
There are many causes of forest degradation that include converting forests to land agriculture, over harvesting of industrial wood and fuel wood, overgrazing, insect, pests and diseases, fire and extreme climatic events such as storms (FAO, 1999). Afforestation programmes are a common policy response for developing countries in the tropics to deal with environmental and economic problems caused by widespread deforestation.

It is widely argued that devolution of natural resource management is the most viable option for ecological and economic sustainability of the natural resources (Conroy et al. 2002). Participation of local communities is one of effective approaches in forest management essentially means sustainable use and management of natural resources by people, living in and around a region integrated ecologically, socially and culturally (Maharjan, 2000).

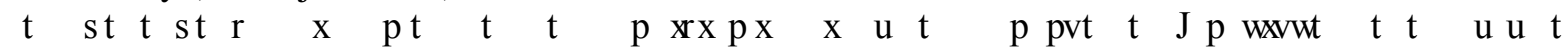
dependence means that the people have a higher stake in the forest, which is reflected in their level of participation (Lise, 2000). Therefore, community action is influenced by forest dependency (Ostrom et. al.1993). Social solidarity is one of the effecti $\mathrm{t}$ upr $\mathrm{u} t \mathrm{~s} t \mathrm{t} \quad \mathrm{p} \times \mathrm{xx}=\mathrm{c}$ wt $\mathrm{t}$; $\mathrm{w}$ has more motivations to participate, has more level of participation. Social participation (membership of community groups organized), is effective factor for level of participation in forestry activities.

\section{OBJECTIVE}

The purpose of the study is to examine how residents of Sittilingi valley of Dharmapuri district in the northern Tamil Nadu view conservation issues that affect all of the people who live in the valley. The main objective of the study is to estimate the willingness of local residents to allocate their personal economic resources to adopt natural resource conservation practices and structures on their land holdings and in common lands of the valley. The study also aims to investigate about the motivating socio

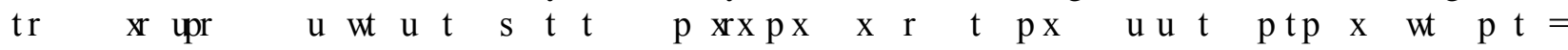
Information derived from the study should be useful for future environmental planning and conservation programme implementation in the valley.

\section{METHODOLOGY}

The study was conducted in Sittilingi Valley of Dharmapuri district of northern Tamil Nadu during February 2010. In this valley, Sittilingi and Naikuthi with large number of tribal population were purposively selected for this study. From each tribal village, 50 farmers were selected randomly for the purpose to have a total sample size of 100. Based on the criteria of land ownership of at least 1 acre (0.4 ha) within the designated study area, the respondents were selected. The selection criteria of property ownership of equal to or greater than 1 acre ( 0.4 ha) was chosen based on the assumption that owners of properties with smaller land holdings usually do not have the types of natural resources problems assessed in this study.

\subsection{MEASURING INDEPENDENT VARIABLES AND PERSONAL FEATURES OF THE RESPONDENTS}

For measuring level of social participation, the respondents were asked questions in relation to each variable and total score of statements for each variable organized final score of that variable. These variables are listed in Table 1 that shows names, labels and units of each quantitative variables. All the qualitative variables are converted into quantitative variables. In total, 10 quantitative variables are derived and used in the study. In order to get an insight into the composition of the interviewed 100 forest dwellers, the distribution of personal features of the respondents are presented in Table 2.

Proceedings of the 15 ${ }^{\text {th }}$ International Forestry and Environment Symposium, 26-27 November 2010.

Published by Department of Forestry and Environmental Science, University of Sri Jayewardenepura, Sri Lanka. 
Table 1: Names, labels and units of the quantitative variables used in the study

\begin{tabular}{|l|l|l|l|}
\hline Name of variable & Scale & Unit & Label \\
\hline Age & $18-65$ & Year & Age \\
\hline Level of literacy & $1-4$ & - & LIT \\
\hline Level of Annual Income & $25000-150000$ & Rupees & AI \\
\hline Household size & $3-10$ & Person & HS \\
\hline $\begin{array}{l}\text { Level of participation in capacity building programmes } \\
\text { by government and agencies and NGOs }\end{array}$ & $0-50$ & Hour & CBP \\
\hline Forest dependency & $0-35$ & - & DF \\
\hline Social participation & $0-25$ & - & SP \\
\hline Social solidarity & $0-35$ & - & SS \\
\hline Economic motivation & $0-25$ & - & ECOM \\
\hline Social motivation & $0-35$ & - & SM \\
\hline
\end{tabular}

\subsection{TOOL AND TECHNIQUES}

We collected data from the forest dwellers (the target group) with a pre tested and structured questionnaire. Content validity of the questionnaire was obtained by group of specialists to determine its validity. A pilot study was conducted in Sittilingi village in the valley to test the validity and to improve the standard of the questionnaire. Cronbach's alpha was used to measure the reliability of the index measuring level of participation in afforestation and development of forest areas and the index was worked out at 0.86 indicating the mentioned variable has high reliability.

Table 2: Personal features of forest dwellers of Sittilingi valley

\begin{tabular}{|l|l|l|}
\hline Features & $(\%)$ & Frequency \\
\hline Age group & & \\
\hline$<35$ & 28 & 28 \\
\hline $35-44$ & 40 & 40 \\
\hline$>45$ & 32 & 32 \\
\hline Education levels & & \\
\hline Illiterate & 44 & 44 \\
\hline Primary school & 12 & 12 \\
\hline Secondary school & 44 & 44 \\
\hline Graduate and above & 0 & 0 \\
\hline Household size & & \\
\hline$<3$ & 8 & 8 \\
\hline $3-5$ & 80 & 80 \\
\hline$>5$ & 12 & 12 \\
\hline Annual income & & \\
\hline 25000 and low & 13 & 13 \\
\hline $25001-50000$ & 37 & 37 \\
\hline $50001-75000$ & 40 & 40 \\
\hline $75001-100000$ & 4 & 4 \\
\hline 100001 and above & 6 & 6 \\
\hline
\end{tabular}

Proceedings of the $15^{\text {th }}$ International Forestry and Environment Symposium, 26-27 November 2010.

Published by Department of Forestry and Environmental Science, University of Sri Jayewardenepura, Sri Lanka. 


\section{THEORETICAL MODELLING}

Traditional Diffusion Model (Rogers, 1995) was used in the present study since the model has been used extensively in social science research focused on the adoption of new technologies, behavioral practices and other innovations.

\subsection{TRADITIONAL DIFFUSION MODEL}

Diffusion model basically asserts that decision making about the adoption of anything is a function of exposure to relevant information about the innovation being assessed. If potential adopters perceive that adoption of a specific innovation will contribute to the resolution of identified problems, then they should have a higher probability of adopting. Diffusion theory asserts favorable attitudes toward the innovation being assessed will encourage adoption and unfavourable attitudes will increase the probability the innovation will be rejected. The diffusion model states that the lack of knowledge and lack of sufficient economic resources to implement are common barriers to adoption. Subsidies and technical assistance apart from knowledge on impact of conservation practices will encourage adoption of conservation practices and structures.

\subsection{VARIABLES USED IN THE MODEL}

Respondents were asked to provide information about perceived environmental and natural resources problems within the Sittilingi valley and about specific actions they would be willing to take to address the issues identified. The factors assessed in the study were measured as follows:

Willingness to invest in conservation was designated as the dependent variable for the study and was measured by asking respondents to indicate the amount of money they would be willing to invest for resource conservation issues on their property. The response categories included on the questionnaire are as follows: none (weighted 0), less than Rs 1000 (weighted 1), Rs 1000 to 1999 (weighted 2), Rs 2000 to Rs 4999 (weighted 3), Rs 5000 to Rs 9999 (weighted 4) and more than Rs10000 (weighted 5). Categories 1 through 5 were combined into one category to get a dichotomous dependent variable with 0 representing those not willing to invest money in conservation and 1 representing those who would be willing to invest in conservation on their lands and public lands.

Table 3: Amount of money Sittilingi valley residents are willing to allocate for conservation

\begin{tabular}{|l|l|l|}
\hline S1. No. & Amount of money (Rupees) & Percent of respondents \\
\hline 1. & None & 60 \\
\hline 2. & $<1000$ & 24 \\
\hline 3. & $1000-1999$ & 10 \\
\hline 4. & 2000 to 4999 & 4 \\
\hline 5. & 5000 to 9999 & 2 \\
\hline 6. & $>10000$ & - \\
\hline
\end{tabular}

The predictive variables used to represent the diffusion concepts discussed in the theory section are attitude toward conservation, importance of subsidies, assistance to adopt, knowledge of impacts and concern for soil fertility/nutrient management. The predictive variables were measured as follows:

Attitude towards conservation was included in the study because diffusion theory places considerable emphasis on the role of attitudes in the adoption and decision-making process. The variable was measured

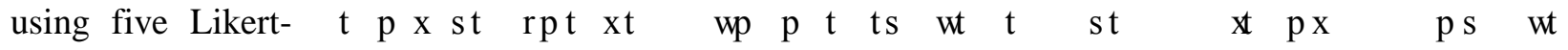

Proceedings of the 15 ${ }^{\text {th }}$ International Forestry and Environment Symposium, 26-27 November 2010.

Published by Department of Forestry and Environmental Science, University of Sri Jayewardenepura, Sri Lanka. 
importance of the following: natural areas (forests), water quality, improving biodiversity, controlling flooding, and learning about natural resources. The possible responses ranged from strongly disagree (weighted 1) to strongly agree (weighted 5). The reliability of the scale was assessed by item analysis which produced an alpha coefficient of reliability (Cronbach, 1951) of 0.89. An alpha of this magnitude indicates the responses to the scale items are highly correlated and that the weighting values can be legitimately summed to form a composite scale score (see Table 6 for scale items and the distribution of responses). Higher scale scores indicate more positive attitudes toward conservation.

Importance of subsidies was included in the study because diffusion theory argues that technical and economic subsidies can remove financial/knowledge barriers to adoption. It was expected that individuals who placed higher importance on subsidies would be less willing to invest their own resources in conservation on their property. This variable was measured using two Likert-type scale items and the respondents were asked to indicate the relative importance of technical and financial assistances when making adoption decisions about conservation practices and structures. The possible responses ranged from strongly disagree (weighted 1) to strongly agree (weighted 5) that technical and financial assistance are important when making decisions on adoption of conservation measures.

Assistance to adopt was included in the study as a second measure of the importance placed on incentives in the adoption decision making process. It was expected that individuals who desired assistance would be less willing to invest their own resources in conservation. This variable was measured by asking the respondents to select the types of incentives that would encourage them to participate in conservation programmes. Incentives assessed were as follows: technical assistance, subsidies, financial assistance for vegetation improvements, and financial assistance for structural improvements. A checked response received value of 1 and a blank response received 0 .

Concern for soil fertility/nutrient management was measured by asking respondents if soil fertility/nutrient management is a concern on their property. It was expected that individuals who were concerned about soil fertility and nutrient management problems would be more willing to invest in conservation efforts that could reduce degradation of soil resources. A positive response received a value of 1 and a blank response received a value of 0 .

It was reasoned that respondents who lived at the site of the property being assessed would be more aware of environmental problems than non-resident property owners. It was expected that residents would be more aware of environmental problems than absentee land owners and would be more willing to invest in conservation to improve the environment in which they were living. Residence was measure by asking respondents to indicate if they lived at the property being assessed. A positive response received a value of 1 and a blank response received a value of 0 .

\subsection{MEASURING FOREST DWELLERS' PARTICIPATION IN AFFORESTATION AND DEVELOPMENT OF FOREST AREAS}

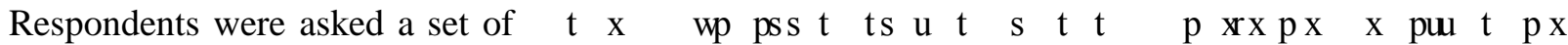
and development of forest areas. These statements were rated on a five-point scale from 0 to 4 . These statements are listed in Table 4. Among five important statements the residents of Sittilingi valley gave top priority for planting trees around their homes as evidenced by highest mean of 3.12 out of 4 and less standard deviation and coefficient of variation. They gave least priority for planting trees in barren and public lands of the village.

Proceedings of the $15^{\text {th }}$ International Forestry and Environment Symposium, 26-27 November 2010.

Published by Department of Forestry and Environmental Science, University of Sri Jayewardenepura, Sri Lanka. 
Table 4: Priority of forest dwellers for development programmes of forest areas

\begin{tabular}{|l|l|l|l|l|}
\hline Priority & CV & SD & Mean* & Statement \\
\hline 1 & 0.312 & 0.974 & 3.12 & Planting trees around homes \\
\hline 2 & 0.649 & 1.876 & 2.89 & Planting in degraded areas \\
\hline 3 & 0.468 & 1.157 & 2.47 & Planting trees in boundary of farmlands \\
\hline 4 & 0.653 & 1.529 & 2.34 & Seeding in natural areas \\
\hline 5 & 0.761 & 1.614 & 2.12 & Planting in barren lands in the village \\
\hline
\end{tabular}

* Range of means is between zero and four

\section{RESULTS AND DISCUSSION}

\subsection{SOCIAL AND ECONOMIC FEATURES OF FOREST DWELLERS IN THE VALLEY}

The age of respondents ranged from 18 to 65 years. The respondents were relatively middle age with an average age being 42 years. Table 2 shows that the largest proportion of respondents was in the (35-44) year-old category ( 40 per cent). About 44 per cent of the respondents were illiterate and equal number had completed secondary school (10 years of education). Among the tribal farmers a sizeable amount of illiteracy is still prevailing. It is heartening to notice that those who started schooling completed their school education at least. The average annual family income of the respondents was Rs. 52687, with 44 per cent of them earning annual family income in the range of 50000 and 75000 and 50 per cent of them were earning less than the average. It was good to notice that 88 per cent of the tribal families were small to medium sized one comprising 5 or less members.

Willingness to invest economic resources for conservation is presented in Table 3. Majority of study respondents were not willing to spend any money on natural resource conservation on their property. Over 60 per cent of the study respondents indicated they would not spend one rupee on conservation efforts on their property. Only 34 per cent indicated they would be willing to spend from Re1 to Rs 1999 and just above 5 per cent ( 6 per cent actually) indicated they would spend more than Rs 2000 . No one was ready to allocate more than Rs 1000 for the purpose. These findings are contrary to common expectation that residents of forests would be willing to pay for conservation.

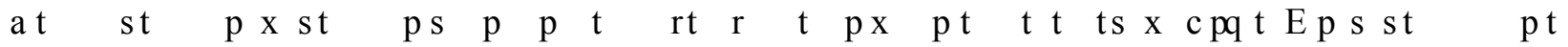
that study respondents were basically very positive toward natural resources conservation as assessed in the study. Respondents were most positive towards statements about encouraging the maintenance of water quality and improving biodiversity. More than 50 per cent of the respondents were positive towards all the statements by either strongly agreeing the statements ant at least agree them. Expectation for good quality drinking water by conservation aspects was the major item that 77 per cent of the forest dwellers agreed about.

\subsection{LEVEL OF PARTICIPATION}

By grouping the respondents with respect to level of participation in afforestation and development of forest areas, it turned out that level of participation of 24 respondents was lowest, while this level for 11 of the respondents was highest (Table 5). Only less than one third of the forest dwellers were participating in the afforestation and forest development programmes spontaneously and willingly and about 69 per cent of the forest dwellers think otherwise. They had a view that these works are developmental works and these are duty of the state. The government and other implementing agencies have to spend a considerable amount of time, money and efforts to make them to participate in such programmes

Proceedings of the 15 ${ }^{\text {th }}$ International Forestry and Environment Symposium, 26-27 November 2010.

Published by Department of Forestry and Environmental Science, University of Sri Jayewardenepura, Sri Lanka. 
Table 5: Participation of the level Sittilingi forest dwellers in forest development programmes

\begin{tabular}{|l|l|c|}
\hline Participation group & No. of respondents & Scale \\
\hline Group 1 (lowest) & 24 & EAD \\
\hline Group 2 (low) & 45 & $6.26-12.50$ \\
\hline Group 3 (high) & 20 & $12.51-18.75$ \\
\hline Group 4 (highest) & 11 & FD \\
\hline Total & 100 & \\
\hline
\end{tabular}

Note: Maximum: 24, minimum: 0, mean: 12.94, standard deviation: 5.92, scale: 0-24

Table 6: Attitude of Sittiligi valley residents towards conservation of natural resources $(n=100)$

\begin{tabular}{|l|l|l|l|l|l|l|l|}
\hline \multirow{2}{*}{ Statements } & \multicolumn{3}{|l|}{ Strongly disagree } & \multicolumn{2}{l|}{ Strongly agree } & Mean & SD \\
\cline { 2 - 9 } & 1 & 2 & 3 & 4 & 5 & score & \\
\hline It is important that I live in forests & 5 & 5 & 32 & 18 & 40 & 3.83 & 1.16 \\
\hline Expecting good water quality & 4 & 4 & 15 & 24 & 53 & 4.18 & 1.08 \\
\hline Conservation improve biodiversity & 11 & 15 & 24 & 29 & 21 & 3.34 & 1.27 \\
\hline Conservation practices will reduce flooding & 8 & 5 & 24 & 19 & 44 & 3.86 & 1.26 \\
\hline Like to learn more to protect natural resources & 6 & 7 & 36 & 19 & 32 & 3.64 & 1.17 \\
\hline
\end{tabular}

Notes: Alpha $=0.89$. Mean scale score $=18.85$.

Table 7 explains the importance of subsidies in adoption of natural resources conservation practices and structures as perceived by the residents of Sittilingi forest valley. From the Table it is clear that in the adoption decision-making process, technical assistance and financial assistance were equally perceived to be important. About 61 per cent of the respondents perceived financial assistance is needed for adoption of conservation practices and equal amount of (62 per cent) opined that technical assistance is also needed for adoption of conservation practices.

Table 7: Importance of subsidies in adoption of conservation practices among Sittiligi valley residents $(\mathrm{n}=100)$

\begin{tabular}{|l|l|l|l|l|l|l|l|l|l|}
\hline Statements & \multicolumn{3}{|l|}{ Strongly disagree } & \multicolumn{3}{l|}{ Strongly agree } & Mean & SD \\
\cline { 2 - 8 } score & & \\
\hline $\begin{array}{l}\text { Financial assistance is needed for } \\
\text { adoption of conservation practices }\end{array}$ & 9 & 5 & 25 & 28 & 33 & 3.71 & 1.23 \\
\hline $\begin{array}{l}\text { Technical assistance is needed for } \\
\text { adoption of conservation practices }\end{array}$ & 10 & 5 & 23 & 27 & 35 & 3.72 & 1.27 \\
\hline
\end{tabular}

While analyzing for types of assistance that would increase the probability of participating in natural resources conservation programmes, subsidies and technical assistance were the major items of preference by the respondents as viewed by equal number of respondents (Table 8). Other types of incentives were mentioned relatively infrequently. Such a finding is inconsistent with research focused on technology-intensive farm operators who tend to be motivated to participate in conservation programmes by financial and technical assistance (Cooper 2003).

Proceedings of the $15^{\text {th }}$ International Forestry and Environment Symposium, 26-27 November 2010.

Published by Department of Forestry and Environmental Science, University of Sri Jayewardenepura, Sri Lanka. 
Table 8: Assistance factors that would increase the probability that Sittiligi valley residents would participate in conservation programmes $(n=100)$

\begin{tabular}{|l|l|l|}
\hline S1. No. & Factors & Percentage of respondents \\
\hline 1. & Subsidies & 62 \\
\hline 2. & Technical assistance & 59 \\
\hline 3. & Compensation for lands & 35 \\
\hline 4. & Financial assistance for vegetative improvements & 20 \\
\hline 5. & Financial assistance for structural improvements & 18 \\
\hline
\end{tabular}

Note: Respondents were permitted to select more than one response.

Among the perceived natural resources concerns of the dwellers of Sittilingi valley the most frequently mentioned natural resource concern for study respondents was soil fertility/nutrient management followed by erosion, biodiversity and flooding (Table 9).

Table 9: Natural resources concerns as perceived by Sittiligi valley residents $(n=100)$

\begin{tabular}{|l|l|l|}
\hline Sl. No. & Concern & Percentage of respondents \\
\hline 1. & Biodiversity & 34 \\
\hline 2. & Flooding & 28 \\
\hline 3. & Erosion & 37 \\
\hline 4. & Soil fertility/nutrient management & 48 \\
\hline
\end{tabular}

Note: Respondents were permitted to select more than one response.

\subsection{HOW FAR THE SOCIO-ECONOMIC VARIABLES AND FOREST DWELLERS' PARTICIPATION ARE CORRELATED?}

Table 10 shows that age was negatively and significantly correlated with the level of forest dwellers' participation in afforestation and development of forest areas. Atmis et al. (2007) reported that age is an important variable in explaining participation.

Level of literacy was positively and significantly $(\mathrm{p}<0.01)$ correlated with level of forest dwellers' participation in afforestation and development of forest areas. This result is accordant to the results of some studies [Lise, 2000]. There is positive and significant correlation between household size and level of forest dwellers' participation in afforestation and development of forest areas. Dolisca et al [Dolisca et $a l$ ] have confirmed this correlation. When the family size is larger the family can spare its elder members for participating in the forest development programmes. Social solidarity is positively and significantly $(\mathrm{p}<0.01)$ correlated with variable of level of forest dwellers' participation in afforestation and development of forest areas. There is positive and significant correlation $(p<0.05)$, between level of forest dependency and level of participation in afforestation and development of forest areas. This result is accordant to the studies done by Lise and Ostrom, et al. There is positive and significant correlation $(\mathrm{p}<0.01)$, between level of participation in extension - education courses and level of participation in afforestation and development of forest areas. Level of Economic and social motivations are positively and significantly $(\mathrm{p}<0.01)$ correlated with level of forest dwellers' participation in afforestation and development of forest areas.

Proceedings of the $15^{\text {th }}$ International Forestry and Environment Symposium, 26-27 November 2010.

Published by Department of Forestry and Environmental Science, University of Sri Jayewardenepura, Sri Lanka. 
Table 10: Correlation between socio-economic variables of the dwellers and their level of participation in afforestation and development of Sittilingi forests

\begin{tabular}{|l|l|l|l|}
\hline Sl. No & Independent variable & r & Label \\
\hline 1 & Age & $-0.374 * * *$ & Age \\
\hline 2 & Literacy & $0.432 * * *$ & LIT \\
\hline 3 & Annual income & 0.008 & AI \\
\hline 4. & Household size & $0.301 * *$ & HH \\
\hline 5. & Participation in capacity building programmes & $0.487 * * *$ & CBP \\
\hline 6. & Forest dependency & $0.214 * *$ & FD \\
\hline 7. & Social participation & $0.305^{* * *}$ & SP \\
\hline 8. & Social solidarity & $0.319 * * *$ & SS \\
\hline 9. & Economic motivation & $0.282^{* * *}$ & EM \\
\hline 10. & Social motivation & $0.512 * * *$ & SM \\
\hline
\end{tabular}

Note: $* * *:(\mathrm{p}<0.01)$ and $* *:(\mathrm{p}<0.05)$

\subsection{HOW FOREST DWELLERS PRIORITIZE THEIR PARTICIPATION IN DEVELOPMENT OF FOREST AREAS IN THE VALLEY?}

Table 3 shows that planting of trees around homes was first priority of the valley residents because of having the lowest extent of coefficient of variation $(\mathrm{CV}=0.312)$. Planting trees in the boundary of the farmlands $(\mathrm{CV}=0.468)$, planting in degraded areas $(\mathrm{CV}=0.649)$ and seeding in natural area $(\mathrm{CV}=$ $0.653)$ planting in barren lands of village $(\mathrm{CV}=0.789)$, respectively, had been allocated priorities from second to fourth. In addition, planting in barren lands of village with the highest extent of coefficient of variation $(\mathrm{CV}=0.761)$ was allocated last priority to itself. Forest dwellers are showing more interest in doing plantation works in their own home and farm lands. When it comes to plantation in common land they opine otherwise. They think it is the duty of the state to do all natural conservation and developmental works in the valley.

\subsection{WHAT MAKES A FOREST DWELLER PARTICIPATE IN THE PROGRAMMES?}

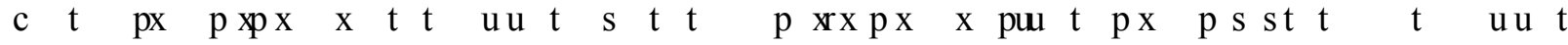
areas in Sittilingi valley of Dharmapuri district in Tamil Nadu, a multiple regression analysis was done. The result is presented in Table 11.

Interpretation of Table 11 indicates that among all explanatory variables, level of participation in capacity building programmes, age, household size, level of economic motivation, social solidarity and level of literacy have entered to regression equation by six steps. Six forgoing variables could explain 51.4 per cent of variation in level of forest dwellers' participation in afforestation and development of forest areas. The following model is estimated by using stepwise method:

hLR $\quad \mathrm{p}:{ }_{1} \mathrm{R} \quad: \quad{ }_{2} \mathrm{Pvt}: \quad{ }_{3} \mathrm{WW} \cdot{ }_{4} \mathrm{TR} \quad: \quad{ }_{5} \mathrm{bb}: \quad{ }_{6} \mathrm{LIT}$

Equation (1) shows that (Y) is used as dependent variable that representing forest dwellers' participation level in afforestation and development of forest areas in Sittilingi valley of Dharmapuri district in Tamil

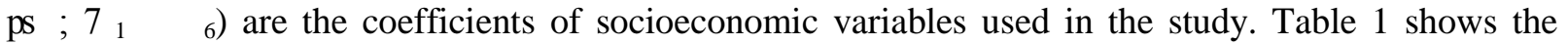
meaning of the variables, which are included in the regression. Consequently, final equation of multiple regression is:

$\mathrm{Y}=-0.799+0.178 \mathrm{CBP}-0.223$ Age $+1.162 \mathrm{HH}+0.35 \mathrm{ECOM}+0.373 \mathrm{SS}+0.823 \mathrm{LIT}$

Proceedings of the 15 ${ }^{\text {th }}$ International Forestry and Environment Symposium, 26-27 November 2010.

Published by Department of Forestry and Environmental Science, University of Sri Jayewardenepura, Sri Lanka. 
Table 11: Regression results explaining dwellers' participation in Sittilingi forests

\begin{tabular}{|l|l|l|l|l|}
\hline Sl. No. & Description & Label & Coefficients & \multicolumn{1}{c|}{$\mathrm{p} \mathrm{t}$} \\
\hline 1. & Participation in capacity building programmes & CBP & $0.178^{* * *}$ & 3.269 \\
\hline 2. & Age & Age & $-0.223^{* *}$ & -4.333 \\
\hline 3. & Household size & HH & $1.162^{* *}$ & 3.592 \\
\hline 4. & Economic Motivation & ECOM & $0.35^{* * *}$ & 3.306 \\
\hline 5. & Social solidarity & SS & $0.373^{* * *}$ & 3.262 \\
\hline 6. & Literacy & LIT & $0.823^{* *}$ & 2.092 \\
\hline 7. & Constant & & -0.799 & \\
\hline & adjusted $\mathrm{R}^{2}$ & & 0.514 & \\
\hline
\end{tabular}

Note: $* *:(\mathrm{p}<0.05)$ and $* * *:(\mathrm{p}<0.01)$

\subsection{WHAT ARE THE KEY FACTORS MAKING THE FOREST DWELLERS OF SITTILINGI VALLEY TO SPEND FOR CONSERVATION?}

The binary logistic regression findings are presented in Table 12 and demonstrate that all the selected socio economic variables viz., knowledge of conservation impacts, concern for biodiversity, attitude towards conservation, concern for soil fertility/nutrient management and residence status were significant $\mathrm{x} \operatorname{str} \mathrm{x} \mathrm{x}$ wt $\mathrm{u} t \mathrm{~s} \quad \mathrm{t} t \quad \mathrm{x}$ ingness to invest economic resources in natural resources conservation on their property.

The only finding that was not consistent with the theoretical perspective used to guide the investigation was for residence. Residents were less likely to invest in conservation than nonresident land owners. This might be due to greater awareness among residents that conservation problems are not problematic on the property being assessed. It may also be a function of nonresident respondents wishing to invest in property they intend to sell. Owners who intend to sell their properties may wish to invest in conservation improvements when they expect to be adequately compensated by an increase in property value. Farmers who do not expect to claim future benefit streams from conservation investments will not adopt conservation practices or structures.

Table 12: Factors influencing willingness to spend personal resources for conservation of natural resources among Sittiligi valley residents $(n=100)$

\begin{tabular}{|l|l|l|l|}
\hline Sl. No. & Predictive variables & $\mathrm{B}$ & $\mathrm{t}$ \\
\hline 1. & Attitude towards conservation & $0.120^{* * *}$ & 2.816 \\
\hline 2. & Knowledge of impacts & $0.683^{* * *}$ & 4.39 \\
\hline 3. & Concern for biodiversity & $1.325^{* * *}$ & 2.47 \\
\hline 4. & Concern for fertility/nutrient management & $2.045^{* * *}$ & 3.06 \\
\hline 5. & Residence & $0.855^{* *}$ & 2.01 \\
\hline 6. & Constant & 4.667 & \\
\hline 7. & $\mathrm{R}^{2}$ & 0.394 & \\
\hline
\end{tabular}

Note: $* *:(\mathrm{p}<0.05)$ and $* * *:(\mathrm{p}<0.01)$

\section{SUMMARY AND CONCLUSIONS}

The findings for Sittilingi forest valley residents are inconsistent with common expectation over adoption of conservation practices as always said in the literatures. Adoption of conservation practices and structures requires extensive investments of economic resources, modification of farming systems,

Proceedings of the $15^{\text {th }}$ International Forestry and Environment Symposium, 26-27 November 2010.

Published by Department of Forestry and Environmental Science, University of Sri Jayewardenepura, Sri Lanka. 
permanent abandon of crop land and other modifications in the farm production system. There is no assured chance of remunerative returns and farm income for such conservation investments from their marginal lands. Tribal farmers are not willing to assume such risks unless they receive economic subsidies from government agencies.

According to results, level of forest dwellers' participation in afforestation and development of forest areas reduced while increasing age of forest dwellers. Hence, we suggest that appropriate implementations are carried out to persuade and empowerment of young people in the tribal villages. The results of research showed that level of literacy of respondents is low; therefore we suggested that indigenous communication channels are used to communicate them.

According to positive and significant correlation between level of economic motivation and forest dwellers' participation in afforestation and development of forest areas, government should distribute free inputs to implement afforestation programmes and facilitate necessary conditions to establish forest nursery.

According to results of correlation coefficient that show a positive and significant correlation between level of social solidarity and level of forest dwellers' participation in afforestation and development of forest areas, it can be suggested that activities of community based organizations should be extended by extension and development agents of forestry sector. Undoubtedly, these activities cause to increase social solidarity among forest dwellers.

\section{REFERENCES}

Atmis, E., I. Dasdemir, W. Lise and O. Yidiran, 2007. Analysis Factors affecting women's participation in forestry in Turkey. J. Ecol. Eco., (60): 787-796.

Conroy, C., A. Misha and A. Rai, 2002. Learning from self-initiated community forest management in Orissa, India. J. Forest Policy Econ., (4): 227- 237.

Cooper, J.C. 2003. A joint framework for analysis of agri-environmental payment programs. American Journal of Agricultural Economics. 85(4):976-987.

Cronbach, L.J. 1951. Coefficient alpha and the internal structure of tests. Psychometrics 16:297-334.

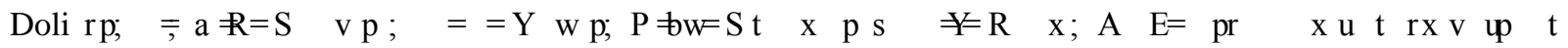
participation in forestry management programs: A case study from Haiti. J. Forest Ecol. Manage., (236): 324-331.

FAO, 1999. State of the world's forests 1999.Rome, $154 \mathrm{pp}$.

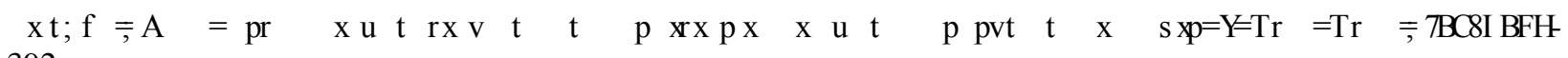
392.

Maharjan, K.L., 2000. Community participation in forest resource management in Nepal. http://www.unu.edu/env/plec/marginal/proceedings/MaharjanCH18.pdf

Ostrom, E., L. Schroeder and S. Wynne, 1993. Institutional Incentives and Sustainable Development, Infrastructure Policies in Perspective (Theoretical Lenses on Public Policy), Westview Press, 266 pp.

Rogers, E.M. 1995. Diffusion of Innovation. Fourth edition. New York: The Free Press.

Proceedings of the 15 ${ }^{\text {th }}$ International Forestry and Environment Symposium, 26-27 November 2010.

Published by Department of Forestry and Environmental Science, University of Sri Jayewardenepura, Sri Lanka. 